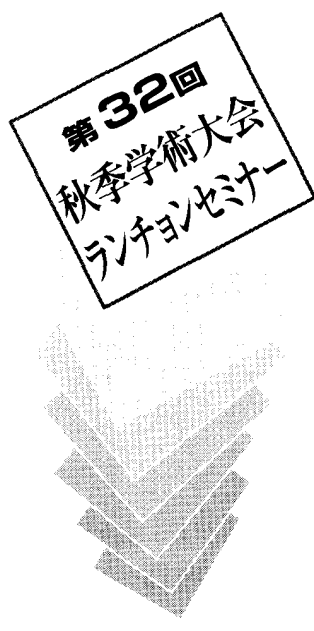

会期：2004年10月22日

会場：グランキューブ大阪

\title{
マルチスライスCTによる心蔵血管イメージング
}

\section{Cardiovascular Imaging by Means of Multi-slice CT in Cardiology}

Shinro Matsuo, and Minoru Horie

Department of Cardiovascular and Respiratory Medicine, Shiga University of Medical Science

\section{はじめに}

わが国の冠動脈造影は, 年々増加の一途をたどって おり，Japanese Coronary Intervention Studyの報告で は，1997年から 2000年の間には，年間約54万件の冠 動脈造影検査が施行されている.このなかで血行再建 術やバイパス術の対象となったものは17万件であっ た.この研究から約 7 割もの患者に診断的冠動脈造影 が行われていることが分かる1．従来の冠動脈造影は 少なからず侵襲性があり, 検査時の合併症の危険は皆 無ではない，一般には入院治療が必要とされ，医療費 に占める割合も年々増加している。このため非侵襲的 に行える簡単な検査の普及が望まれる。

非侵襲的冠動脈検査法であるCTの臨床応用は, 主 に電子ビームCTやへリカルCTを用いた冠動脈石扊化 の定量化が主流であり, 造影剤による冠動脈直接描出 は以前には困難であった。 なぜなら, 冠動脈の画像化 には心拍動や呼吸の影響などの不利な条件があり，良 好な画像描出が困難であった。最近登場した心電図同 期マルチスライスCT(multi-slice CT; MSCT) は, 連 続撮影で得られたデータから任意の時相を取り出し, volume rendering $(\mathrm{VR})$, maximum intensity projection (MIP), multiplanar reconstruction(MPR) 等の画像再 構成法で, 冠動脈の内腔の血流情報と血管壁の情報が 得られるようになった。

滋賀医科大学附属病院では，2002年10月から 8 列 MSCT，そして，2004年11月から16列MSCTを使用し 診療を行っている。 そこで本稿では, 循環器内科の立 場からMSCTによる冠動脈狭窄およびプラーク評洒, 血管形態評価, 心機能評価, そして診断の現状と有用 性について述べる。

\section{CT撮像方法と評価法}

われわれの施設で使用しているMSCTは，東芝社製
Aquilion (8 列) とシーメンス社製Sensation Cardiac (16 列)である (Fig. 1)。ワークステーションはAMIN Zio M900 Singleを用いている. また，心電計はフクダ電 子Dyna Scopeを, 自動注入器は根本杏林堂 A-250を使 用している. 検査方法は, 静脈ライン確保 (右手肘静 脈) し，心電図の装着を行い，心電図波形を確認した 後，撮影時の息止めを容易にするために経鼻酸素吸入 (31/min)を行う。位置決め用の単純CT撮像後に, 非イ オン性ヨード造影剤(オプチレイ，タイコヘルスケア ジャパン)を肘静脈から自動注入後, real prep法により 撮像する22. 造影剤は濃度の違うものが数種類ある が，プラーク評価目的ではプラークへの造影効果の影 響を少なくするため，われわれは低濃度 $(320 \mathrm{mgI} / \mathrm{ml})$ のオプチレイを用いている。一回呼吸停止下に心基部 から心尖部へ向かい, 約 $10 〜 15 \mathrm{~cm}$ の範囲をへリカル スキャンにて撮影する.心拍数調整は, 心拍数 60 以上 の場合には $\beta$ 遮断剂セロケン $(40 \mathrm{mg}) 1 \mathrm{tab}$ 使用する (CT撮影約60分前に内服). 気管支喘息など $\beta$ 遮断薬の 使用禁忌の例ではへルベッサー(田辺製薬)を使用する 場合もある。そして, 造影殽の注入のタイミングとス キャン開始の正確な同期は大変重要である. 画像再構 成はretrospective ECG gated reconstructionを行い, 画像 スライス厚 $1 \mathrm{~mm}$ ないし $0.5 \mathrm{~mm}$, 再構成間隔 $0.25 \mathrm{~mm}$, 心拍位相 $70 \%$ で, セグメント再構成法は場合により他 の位相を追加する。プラーク評価やステント内評価に はスライス厚 $0.5 \mathrm{~mm}$ 用いる. 再構成では, 絶対戻し 時間を用いたP波法がある。これは, 拡張末期におけ る心房收縮による心室容積拡大の時相を避けるため に, 再構成幅(時間分解能)の終端を心房収縮開始の指 標であるP波の頂点におく方法である。また，心房細 動や心房性期外収縮などの不整脈がある場合には, 絶 対遅延時間を用いたT波法を用いることがある。これ は心周期のなかで, 心室容積に変化の少ない心位相画 
像を描出するために， T波の終わりに再構成の中心を おく方法である.今までの心電図同期再構成法では心 房細動の場合は適応ではないとされていたが，今後は 使えるようになってくるものと考える．また，各RR 間隔を100等分に分割し，それぞれのRR間隔で相対的 な指定パーセントを中心に再構成する相対遅延パーセ ント法がある. 心拍数が多いと画像の劣化をきたすこ とはよく知られている。症例によって個人差がある が,このほか撮影中の心拍変動によっても画像が劣化 するため注意が必要である．息止め後すぐには徐脈と なることが多く，数秒の間隔をおいてから撮影を開始 する.心拍変動が大きい場合には拡張期が変動するた めに再構成法のなかで相対遅延パーセント法よりも， 絶対遅延パーセント法を用いた画像が良好である場合 がある。

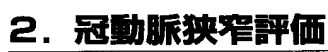

虚血性心疾患患者50例において，同時期に従来の冠 動脈造影とMSCTによる冠動脈造影との比較をした。 冠動脈造影をgold standard としたときのMSCTによる 冠動脈狭窄病変の診断感度は80.2\%, 特異度は95.6\% であった3 6). われわれの施設ではVR画像を参考画像 として用い, axial画像, MPR画像, MIP画像により三 次元画像診断を行ったところ, 冠動脈狭窄病変を正確 に診断することが可能であった。ただし，MSCTの狭 窄度と冠動脈造影の狭窄度は必ずしも一致しないこと は観察方法が違うために起こりうる．冠動脈造影で正 常と診断された場合でも，MSCTによりプラークが存 在し軽度の狭窄病変と診断する症例を経験している。

イマトロンCTによる冠動脈石灰化評価検出は冠動脈 硬化の指標であるが，MSCTにおいてもより鮮明に石 扊化の評価が可能であり, 石灰化の情報は冠動脈疾患 のリスク評価および術前の情報として重要である. 読 影においてはMPR画像，MIP画像を多用する，患者へ の説明には，視覚的に分かりやすいVR画像を用いる ことが多い. 著者は検査により先天性冠動脈起始異常 (単冠動脈)などが偶然に観察された症例を経験した。 右冠動脈や左冠動脈の起始異常が見つかることもあ る.

\section{3. ステント内評侕および石灰化}

現在のインターベンション治療においてはステント 留置が治療の主流である. 現在主流であるステンレ ス・スチールやナイチノールステントの内腔は十分評 価可能である. 最近わが国でも薬剤溶出ステント (drug eluting stent：DES)が使用できるようになり， ステント留置後の新生内膜増殖を抑制することで再狭 窄率が一層減少することが報告されている.われわれ

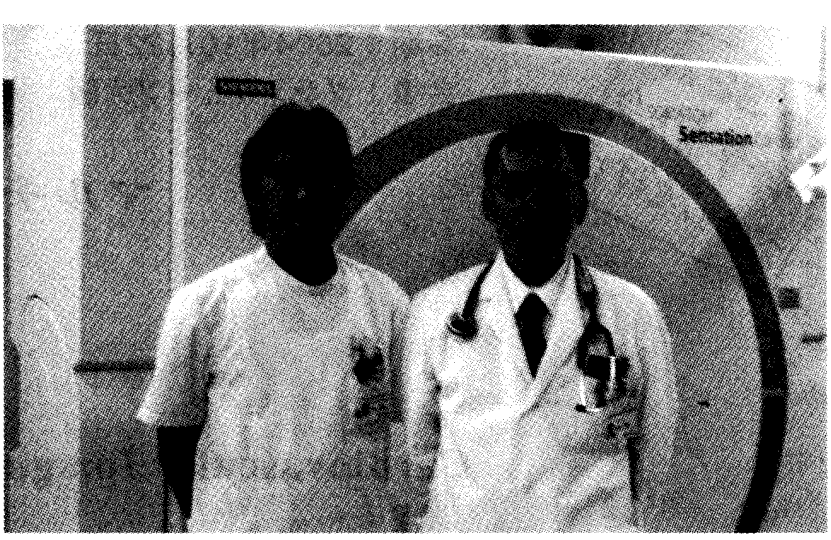

Fig. 1 滋賀医科大学CT室 右は著者, 左は牛尾技師

の施設では，ステントの開存部位の有無をステントに 直交するラインでプロフィールカーブを作製し，ステ ント内のCT值を計測することで診断した。これによ りステントの開存の有無に関しては100\%診断可能で あった $(100 \%: 13 / 13)^{6}$. Fig. 2に例を示す.しかしな がら, ステントの内腔は, ステントによるアーチファ クトのために評価が困難となることが多い. 特にステ ント径が小さいほど評価は困難である，ステント径が $3.5 \mathrm{~mm}$ 以上あり，心拍数が $60 /$ 分以下であれば通常の curved MPR像によってステント内腔の評価を行うこ とができる。われわれは，冠血行再建術後の症例の一 部に対してはMSCTのみで経過観察を行っている. DESによって再狭窄率が減る可能性があり，MSCTに より再狭窄の評価ができれば医療費の抑制や患者負担 の軽減の観点からも有用である。しかし, 実際よりも ステント内は細く描出されることがあり,このため負 荷心筋シンチグラフィによる虚血評価が必要となるこ ともある。

冠動脈の石疢化はMSCTでの冠動脈の内腔の評価に は妨げになり得る．石灰化が多い症例では冠動脈硬化 症の存在するリスクが高いことが報告されている，実 際に高度の石扊化例においては, axial像にて石疢化病 変を観察し内腔の狭窄を評価することが必要である. 高度の石灰化例やステント留置症例ではプロフィール カーブを描いて，解析方法を工夫することにより，ス テントの開存性が評価可能となる．冠動脈細分枝は細 分枝を末梢まで完全に追える場合に細分枝の描出が可 能と判断した。冠動脈細分枝の描出能は右室枝 $(\mathrm{RV}$ branch)において $91 \%$ ，第一対角枝(\#9)においては87 \%であった6).

\section{4. プラーク評傮}

急性冠症候群は, 粥状プラークの崩壤と, これに伴 う血栓形成が急性の心筋虚血を意味する病態学的概念 であるが，虚血性心疾患診断のgold standardである冠 

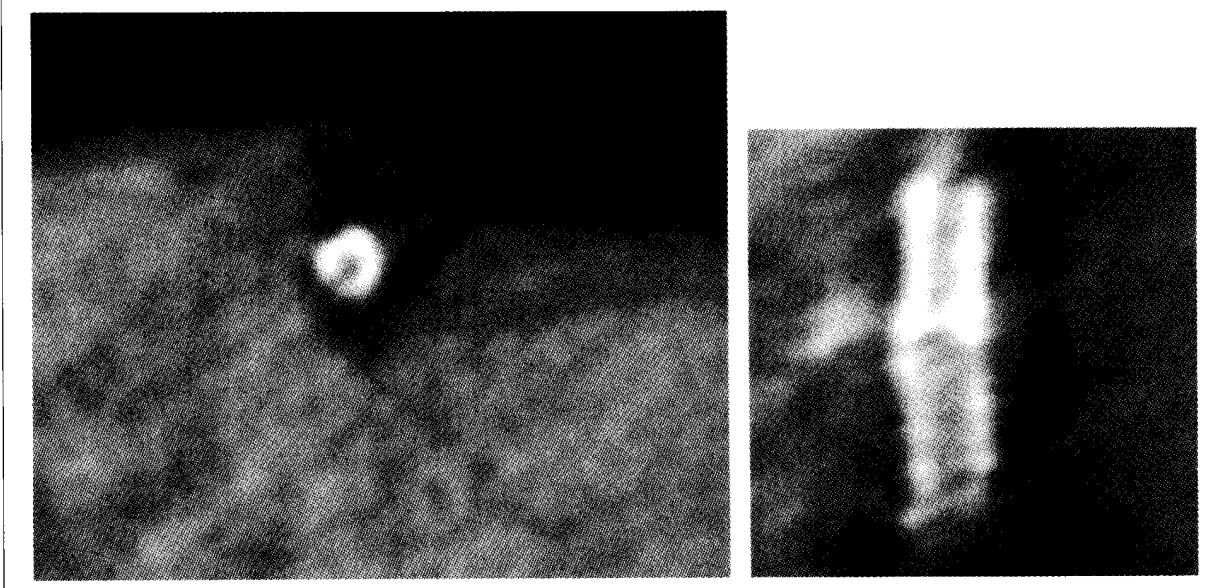

Fig. 2 68歳男性, 狭心症の症例 ス テント留置術 1 年後のフォロー アップ検查. 右冠動脈のセグ メント\#2に留置されたステン 卜画像

(a) ステント部位の短軸断面像

(b) 垂直断面像

動脈造影は血管壁の病態を必ずしも反映せず，狭窄の 有無よりも壁性状評価が可能な検査法が望まれてい る。なぜなら，急性冠症候群の主病因といわれる不安 定プラーク (vulnerable plaque) を観察することは，そ の後の心筋梗塞発症を予知できる可能性があるからで ある．不安定プラークの特徵は薄い線維性皮膜 (fibrous cap) やcalcified nodule,びらん (erosion) が挙 げられる，血管内超音波と血管内視鏡が臨床的に利用 される検査法であるが，多数の症例において外来で臨 床応用するためには，より非侵襲的な評価が必要であ る、われわれは10例，31の狭窄部位においてMSCT冠 動脈内視鏡のプラークの性状評価を比較検討した結 果, lipid coreを含む(破綻しやすい) soft plaque $(n=10$, CT值 $17 \pm 24$ Houns-field単位，HU)，比較的安定な中 間群のintermediate plaque $(\mathrm{n}=8$, CT值 $98 \pm 21 \mathrm{HU})$, 石灰化プラーク (calcified plaque) $(n=13$, CT值

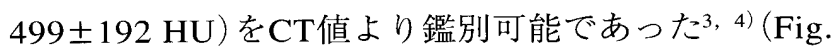
3).これにより血管内超音波 (IVUS)を用いて観察さ れたプラークの所見をMSCTにおいて観察することが でき, IVUSで観察された線維性プラーク, 脂質コア と線維性皮膜の観察がMSCTにおいても可能であっ た. 68歳男性で右肩の痛みを主訴に当院外来を受診 し，心電図は完全右脚ブロックであった症例におい て，血清酵素値，心エコーのいずれにも異常を認めな かった，直ちにMSCTによる冠動脈造影とプラークの 評価を行った，VR画像およびcurved MPR画像では左 前下行枝セグメント\#6に有意狭窄を認めた。狭窄部 に偏在性のプラークを認め, そのCT值は, 10～30HU あった，病変部位の血管は陽性りモデリング (positive remodeling) を認めた. 以上から，この症例は左前下 行枝セグメントの\#6を責任病変とする急性冠症候群 であると診断し，直ちに冠動脈造影と責任病変部にス テント留置術を行った. Fig. 4に示すとおり, プロフ

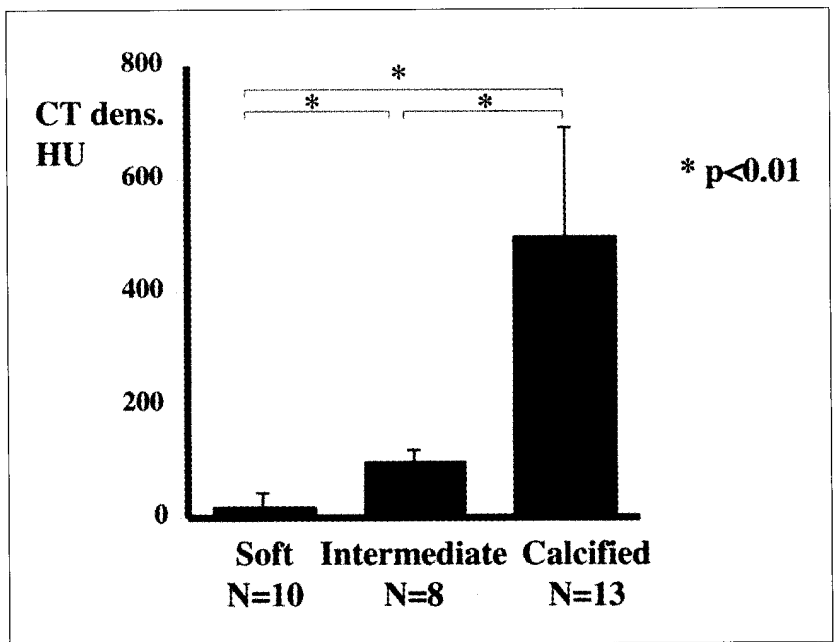

Fig. 3 プラークのCT値とIVUS所見との関係

アイルカーブからCT值を測定した．プラークのCT值 を測定する際には留意しておく点がある，造影による pseudoenhancement, 心拍動による影響, partial volume effect, 石灰化による影響，プラークの不均一性 やプラークそのものへの造影効果などである.これら の要因はCT値に少なからず影響するため, CT值の測 定精度についての血管径や心拍数によって変動する可 能性も報告されているが，基礎的な多くの検討が望ま れる.Fig. 5に左冠動脈主幹部のプラークを観察した 例を示す。病変部位のリモデリングは病变部の近位側 と遠位側の両方を比較し, 病変部の血管径が増大して いれば陽性リモデリングといい，血管径が減少していれ ば陰性リモデリング (negative remodeling) と呼ぶ。血管 内腔が $40 \%$ 程度の狭窄に達すると，血管が外に向かっ て広がり内腔を維持しようとする反応が陽性リモデリ ングである。陰性リモデリングの方が陽性リモデリン グより，ステント留置後の内膜増殖が少なく，ステン 卜留置術後の成績が良い。 また, 陽性りモデリングを 


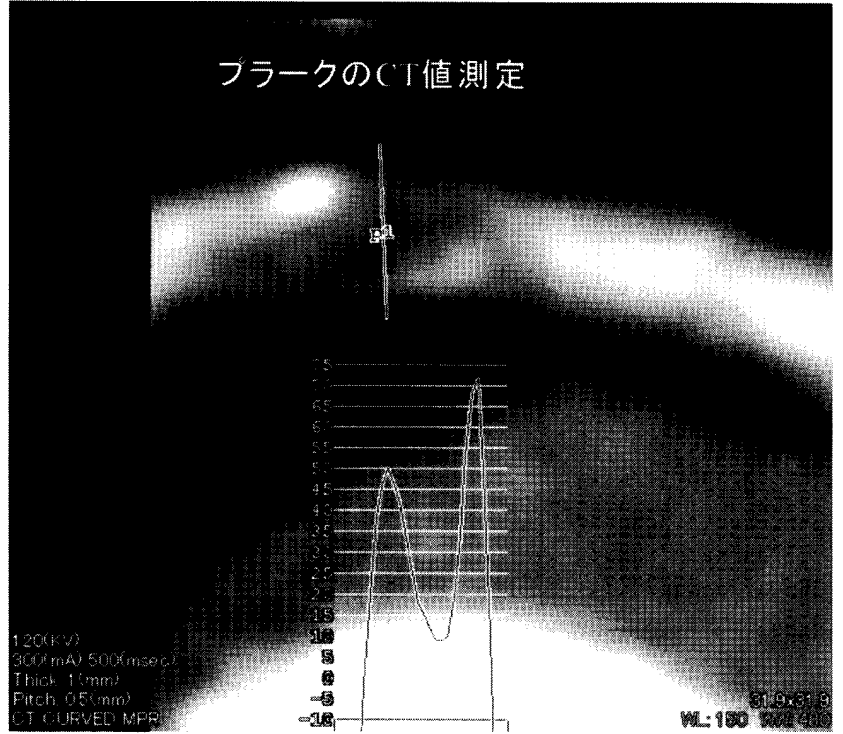

Fig. 4 プロファイルカーブによるCT值の測定

きたしている病変部にはプラークが多いことが分かっ ている。このように近年，陽性リモデリングが脆弱プ ラークの危険因子であるとして注目されるようにな り，その評価にMSCTの有用性か期待されている．今後 は血行再建術の施行前に, 病変部のプラークやリモデ リングの情報を非侵襲的に観察することも循環器内科 医には有用である。また，強力な脂質低下療法により プラークの面積が減少することが, 血管内超音波検査 を用いた研究により明らかにされた，抗動脈硬化薬の 治療効果判定にMSCTを用いた画像診断が臨床応用さ れ，プラーク量を測定できる可能性があると考える. 不安定プラークの性状の特徵は脂質の情報だけではな く, マクロファージ，好中球の浸潤やプラーク内の calcified nodule，血管のリモデリングなどの情報が必 要であり, MSCTでの限界も存在する.

\section{5. 心機能評価}

MSCTでは，冠動脈イメージングと同じデータを用 いて，心機能の解析が可能である。心機能の情報は臨 床医にとって有用である。心機能の解析には, 壁運動 と壁厚増加率の評価, 容積計測 (左室拡張期, 収縮期 容量, 左室駆出率, 心筋重量)心筋灌流(造影剂による 染まり)が含まれる。また, われわれの施設では容積 曲線微分解析ソフト; $\operatorname{VCDiff}($ 第 1 ラジオアイソトー プ研究所）用いることにより拡張能の解析を行うこ とが可能である7゙. シーメンス社製のSensation Cardiac付 属のArgusに㧍いても, 複数の心時相で再構成した画 像から心腔内の輪郭抽出を行い, 各時相の心室容積や 心筋の厚さ等を計算することができる. Fig. 6に心機 能評価の例を示す。虚血性心疾患では, 心筋虚血を生

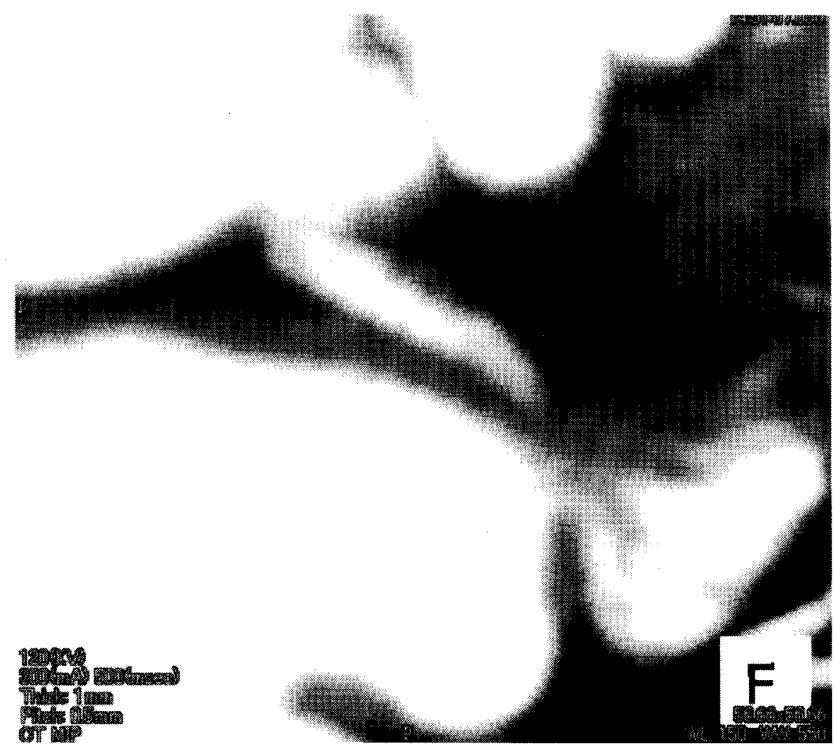

Fig. 5 左冠動脈主幹部のプラーク

じると拡張能異常が起こり, 後に収縮能異常, 左室充 満圧上昇, 心電図变化, そして胸痛を生じる8, 9). 拡 張能評価には, 初期の心疾患での異常を検出できる可 能性があり，臨床上重要である。また，肥大型心筋症 のような非対称性心筋肥大症例においても正確に心機 能を測定できる可能性がある10-12).

多断面の心臓軸断面で動画像を観察することにより 左室内腔の評価と心筋壁厚の増加の観察ができる。広 範囲の貫通性陳旧性心筋梗塞の場合には，梗塞部位の 壁収縮異常とともに心筋壁の非薄化と壁収縮低下が観 察される，小さい範囲の心筋梗塞の場合には，梗塞部 位の壁収縮がみられないが，周囲の壁収縮に引きつら れて左室内腔の動きがほぼ正常にみられるような状態 を観察することもある，心筋壁厚が薄くバイアビリテ イのない心筋に対する血行再建術は, 壁運動の改善は みられないのに対し, 壁厚がありバイアビリティの 保たれている場合には血行再建術後の機能的回復が認 められる。心臓核医学検査がバイアビリティ検査の gold standardであるが，MSCTにより心筋壁厚を正確 に測定することができるため，心筋バイアビリティ有 無の推測がある程度は可能である．CTにおいてはヨ 一ド濃度とCT值が比例するために, 心筋組織内の血 流量あるいは血流量評価の定量的評価がCT值測定に より可能である. 不整脈源性右室心筋症の心室壁の評 価にも有用である (Fig. 7)。ただし，心機能評価は現 在のところ冠動脈評価に付随して得られる情報であ り，検査の主目的ではないことが多い.

\section{6. 解離性大動眽㾇}

解離性大動脈瘤の診断において超音波検査や 


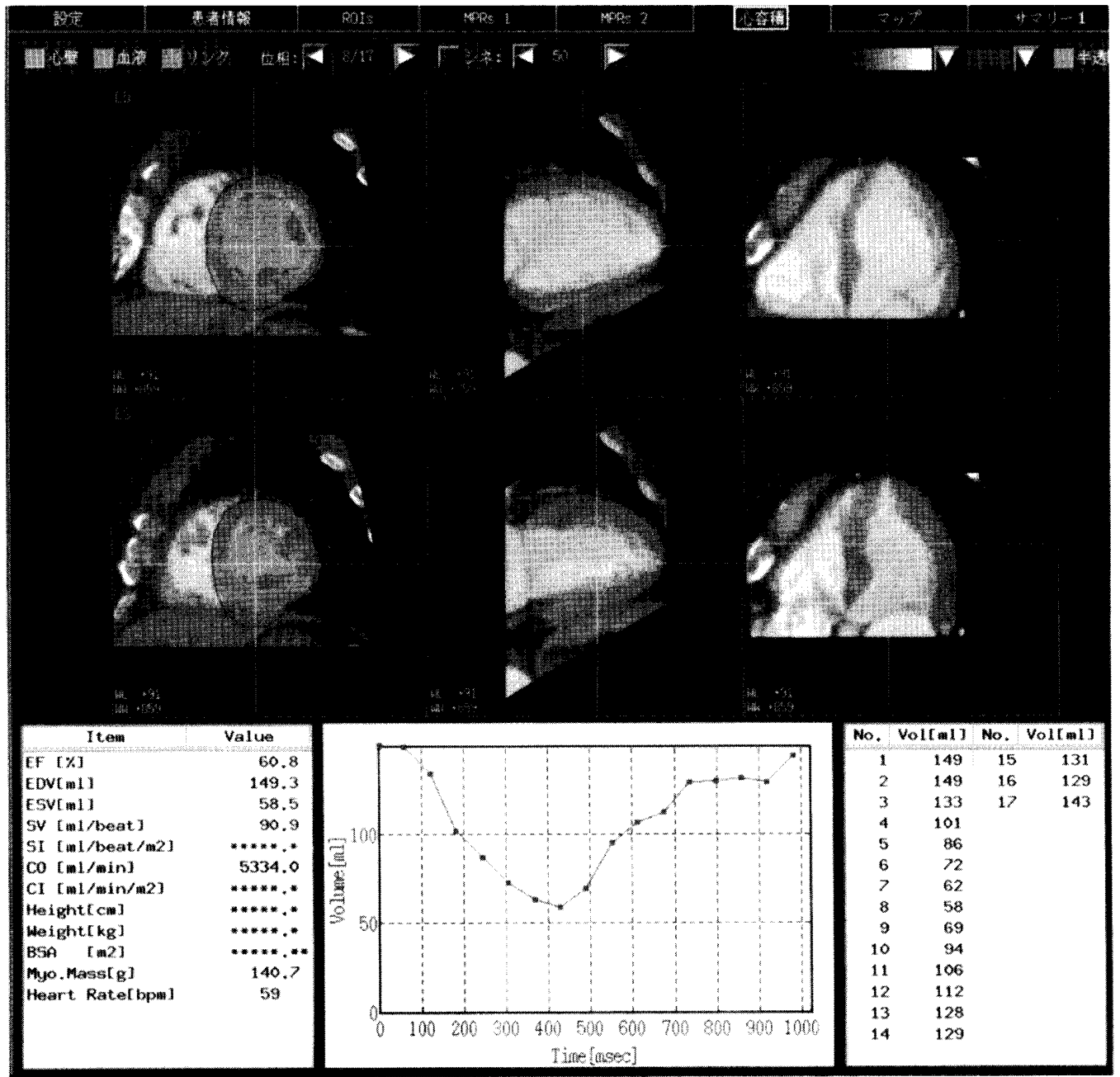

Fig. 6 心機能評価

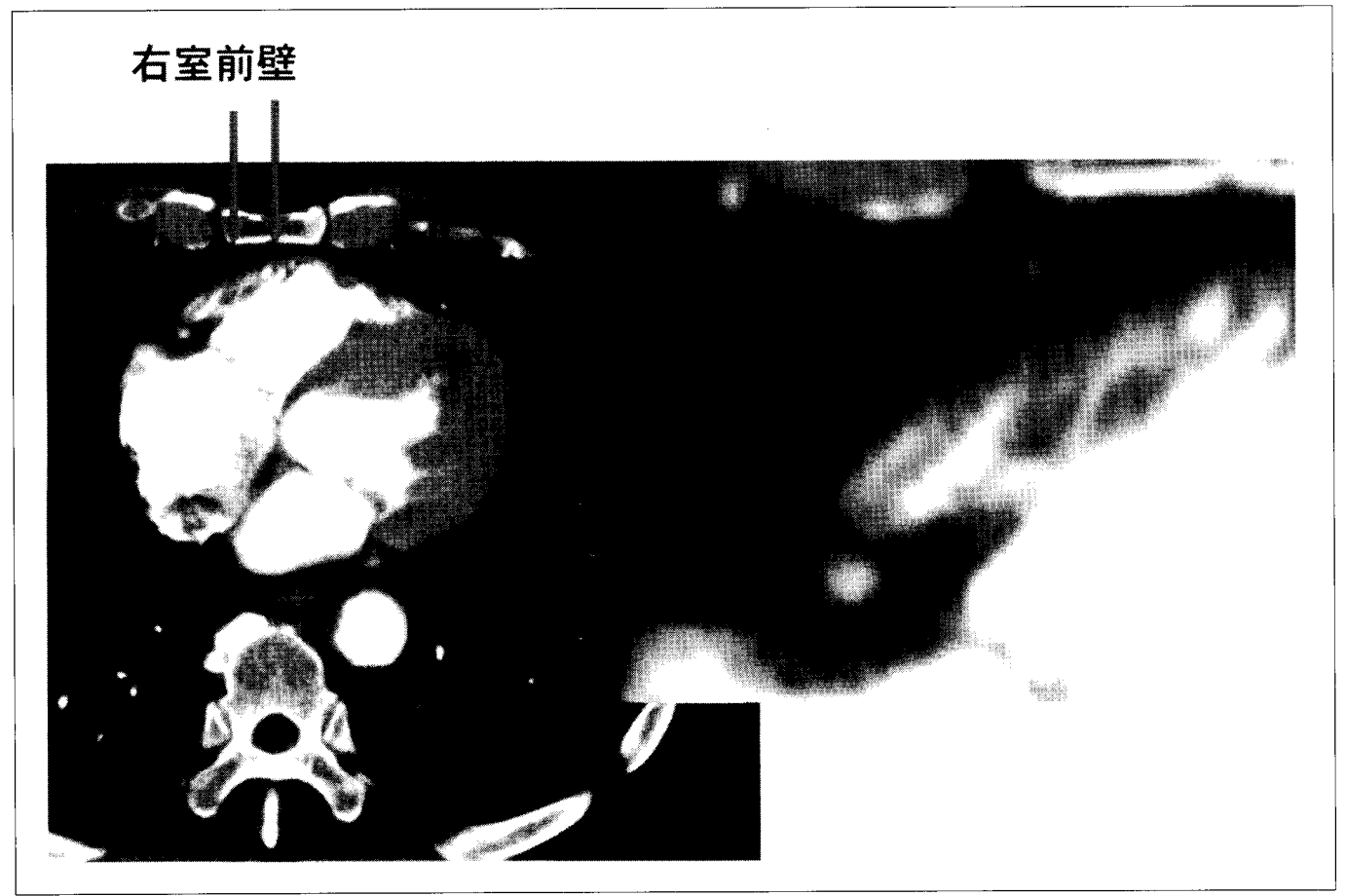

Fig. 7 不整脈源性右室心筋症の心室壁 


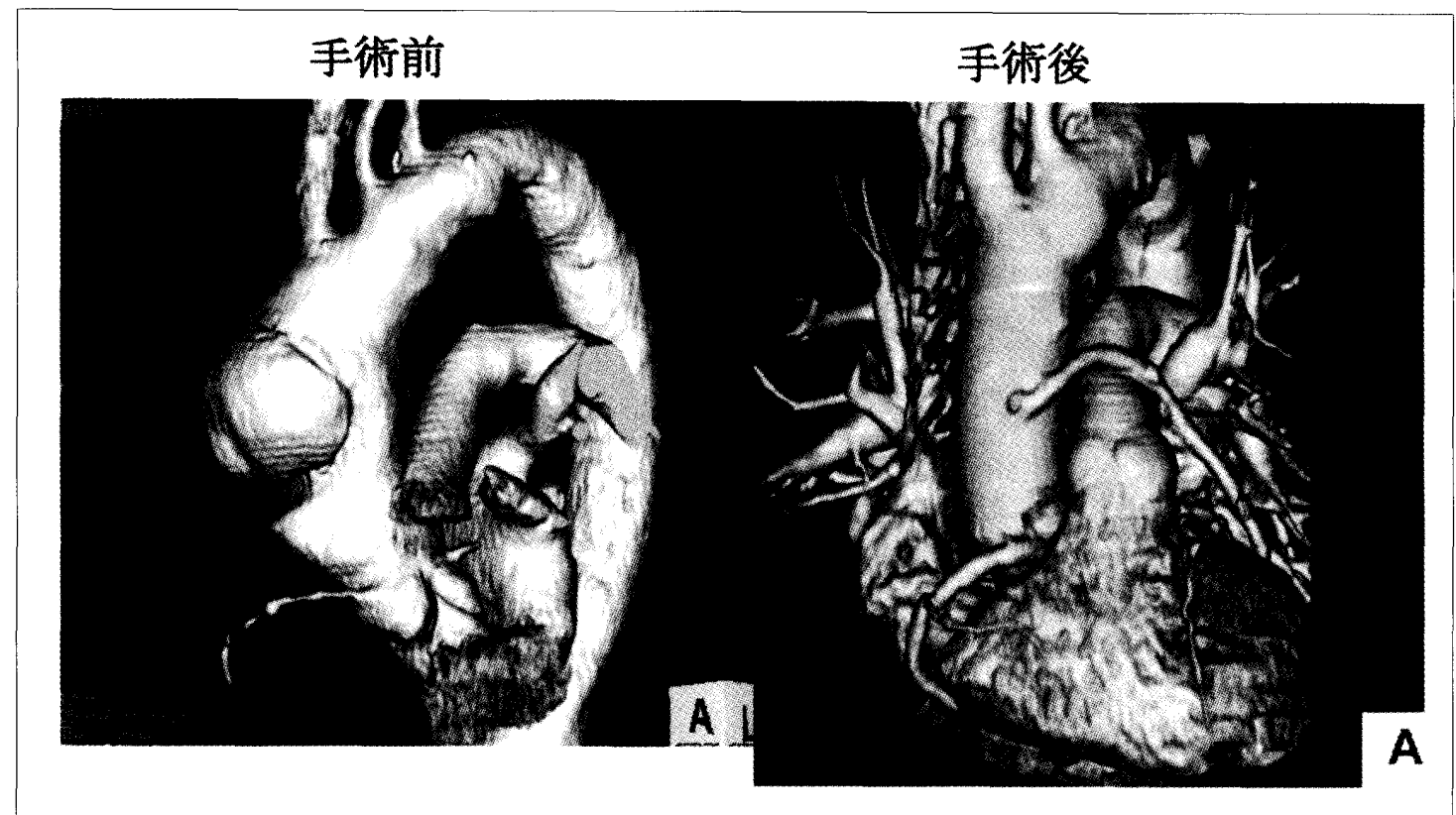

Fig. 8 解離性大動脈瘤と心臟バイパスの同時手術

MSCT, MRIは, 必要不可欠な検査である.胸部痛で 来院した場合で，胸部レントゲンで解離が明らかでな い場合でも的確に診断することができる. 大動脈解離 は広範囲に進展する場合が多く, カテーテルによる造 影が破裂の危険を伴うのに対して，MSCTにより非侵 襲的に血栓化した偽腔の描出や剥離内膜の描出が可能 である.上行大動脈解離に対する人工血管置換術と心 臓バイパス術の同時手術を行った症例をFig. 8に示 す.

\section{7.心臓バイパス術後評価}

現在の16列のMSCTにおいても心臓バイパス術後の 開通性の評価はVR像やcurved MPR画像におういて十分 可能である. 最近は心拍動下冠動脈バイパス手術によ り早期に退院する例が多く, また, 多枝病変や複雑病 変に対するバイパスが増えているのでバイパス吻合部 に対する経過観察だけでなく既存の冠動脈病変につい てもMSCTにより評価することで, 虚血性心疾患治療 の有用な情報が得られる。静脈グラフト, 内胸動脈, 胃大網動脈を用いたグラフトの開存性の評価において 良好な結果が得られている。

\section{8. 心眡畽瑒}

心臓腫瘍には粘液腫や心線維腫といった良性腫瘍や 悪性リンパ腫のような悪性腫瘍などがある. MSCTに より腫瘍の大きさ, 性状だけでなく, 進展度が迅速に 診断できる.Fig.9の症例は左房粘液腫である。原発 性心臓腫瘍全体の 3 割, 原発性良性心臓腫瘍の 4 割 を占める.心腔内のいずれの箇所にも発生しうるが,

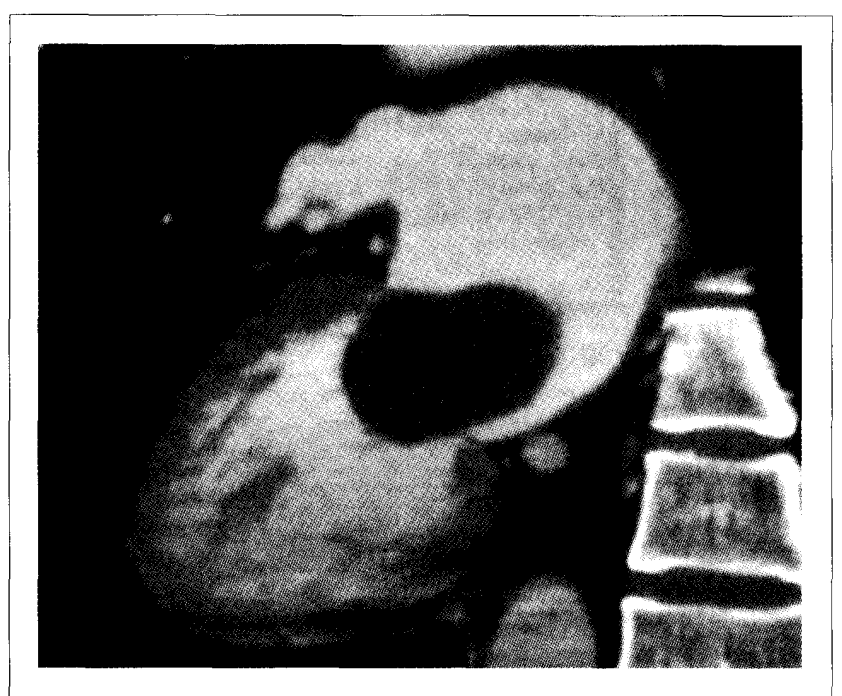

Fig. 9 心臟腫瘍の症例 左房粘液腫

3/4は左心房内の卵円窩領域から発生する有茎性の腫 瘍として認められる。粘液腫は塞栓症や急死の原因と なりうるので, 全例外科治療の適応となり, 診断後す ぐに外科的に切除された.一方, 血管肉腫, 横紋筋肉 腫, 線維肉腫, 要性リンパ腫が代表的な原発性悪性心 臓腫瘍である。その頻度は原発性心臓腫瘍の 1 割以下 である．30歳代から50歳代にかけて好発し, 粘液腫之 異なり右心房が好発部位である。これらの肉腫に対し ては放射線療法や化学療法を行うことが多い. 著者は MSCTでの腫瘍形態所見から悪性腫瘍が疑われたた め, 経皮経管的に腫瘍の生検を行いB細胞悪性リンパ 腫と確定診断した症例などを経験した(Fig. 10)。心臓 腫瘍の迅速な鑑別診断にMSCTは有用である。また， 

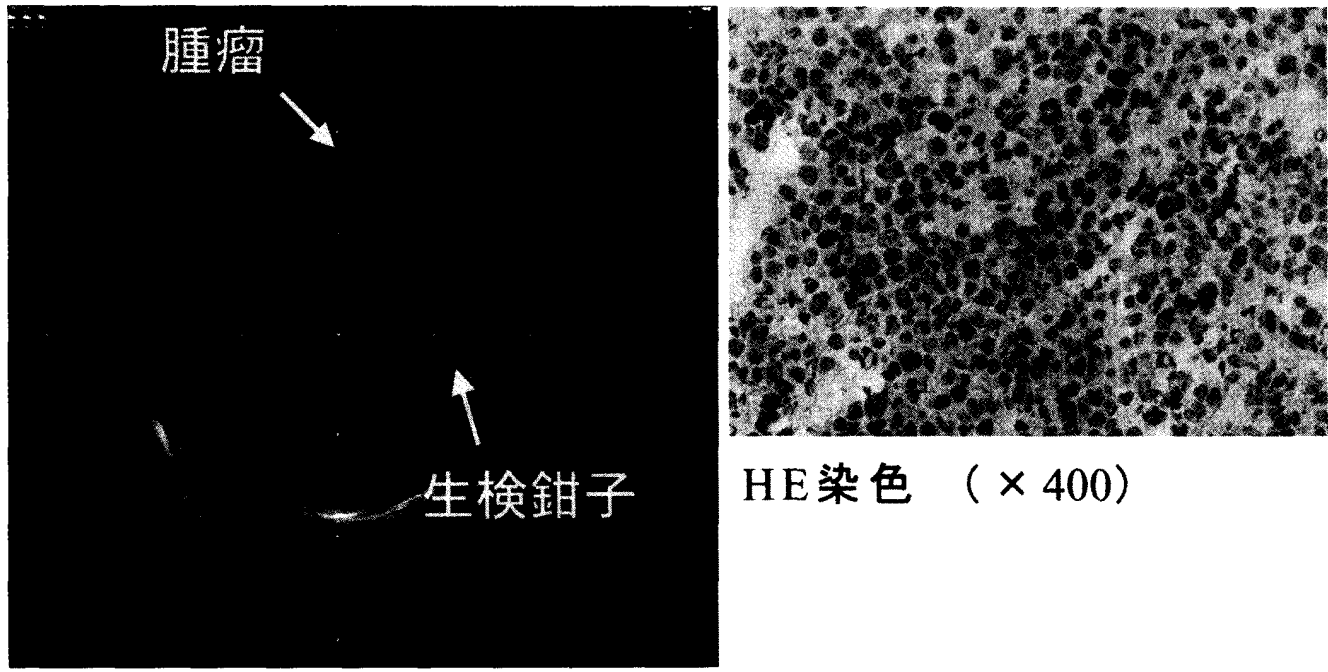

HE染色 $(\times 400)$

Fig. 10 B細胞悪性リンパ腫 （a）血管内エコー画像, (b)生検病理組織. B細胞が多数観察される.

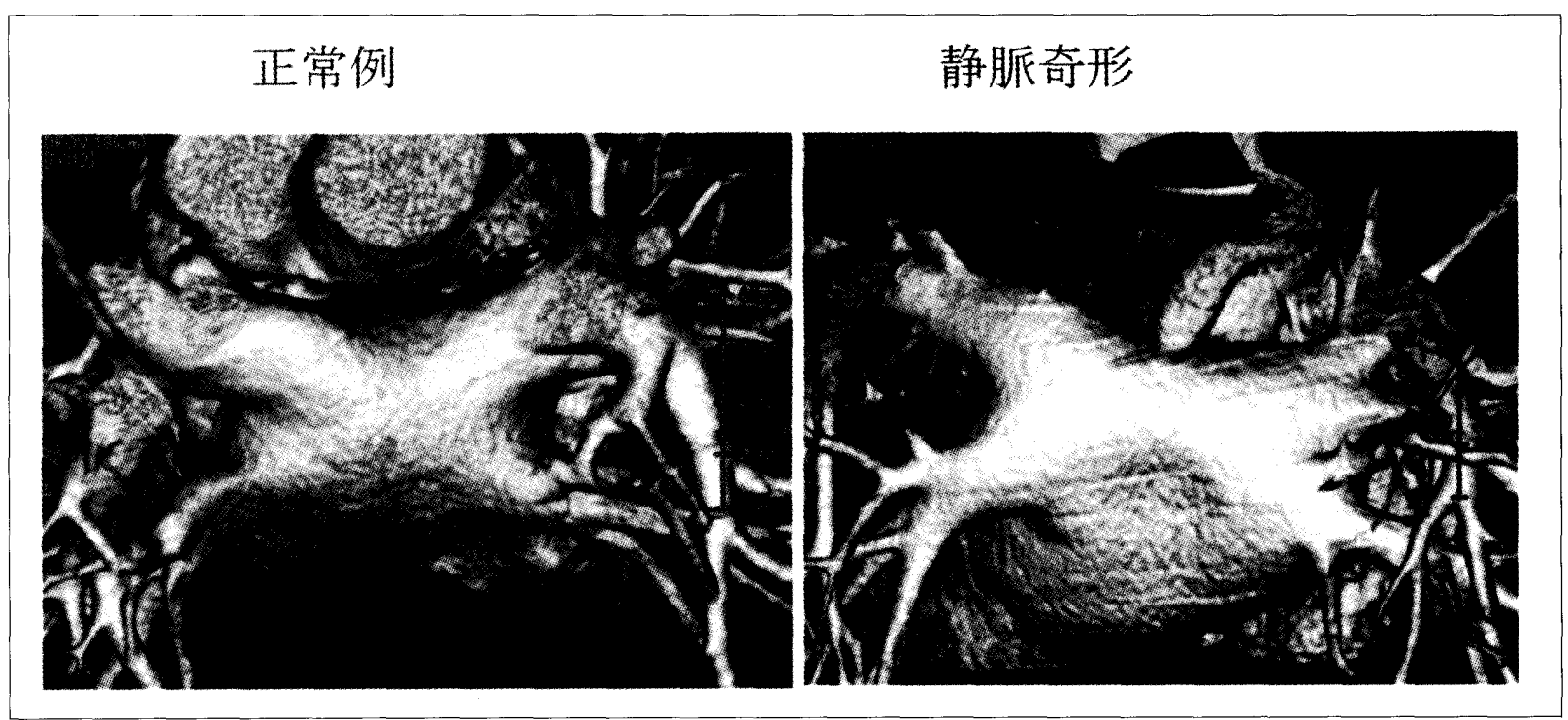

Fig. 11 アブレーション治療前の肺静脈奇形の症例

心エコーでは観察の困難な心尖部や左心耳の血栓の観 察を行うことができる。

\section{9. 心房粗動のアブレーション治療}

心房粗動の多くは右心房の三尖弁輪周囲を旋回する リエントリーを機序とする。この回路を横断するよう に線状に右房壁を高周波通電により加熱し凝固壊死さ せることにより，心房粗動を根治する。このような手 術前の左心房や肺静脈の形態評価にMSCTは大変有用 である。これにより静脈奇形の有無や血管の走行，細 い枝の走行や左心耳の血栓の有無を術前に非侵襲的に 知ることができ，また，術後の経過観察にも有用であ る $^{13)}$ 。手術前に形態情報が得られることで合併症の発 生を予防できる可能性がある. Fig. 11に肺静脈奇形の
症例を示す。心房細動でのMSCTの撮影は, 洞調律に 比べると困難となるが収縮期画像を用いることでほと んどの場合十分な画像が得られる14).

\section{0. 動眽管開存}

動脈管は母親の胎内にいるときは誰にでもある大動 脈と肺動脈を結ぶ管であり, 出生後, 数時間で自然に 閉鎖する．この動脈管が何らかの原因で閉鎖しないた めに，心臓から拍出された血液の一部が大動脈から開 存した動脈管を通り肺動脈に流れる状態を動脈管開存 症 (patento ductus arteriosus：PDA) といい, 比較的頻 度の高い先天性心疾患の一つである。Fig. 12は連続性 雑音が聴診され, 動脈管開存症と診断した症例であ る. 


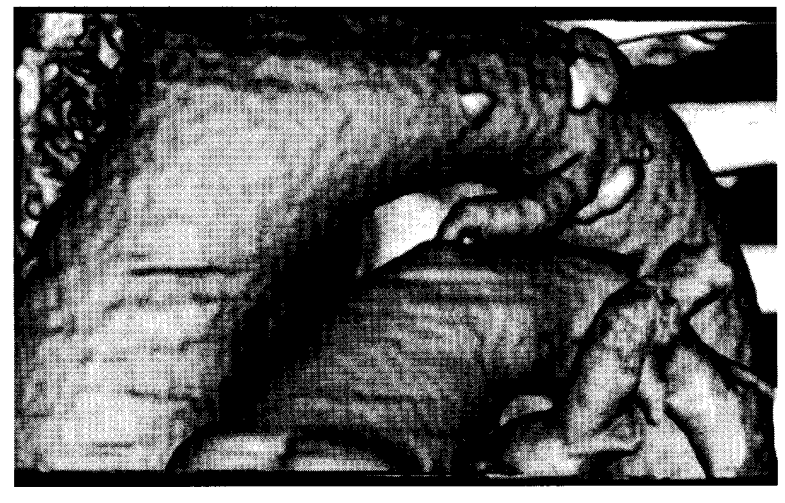

Fig. 12 動脈管開存症の症例

\section{1 . 今後の展開}

心電図同期MSCTは，一度の撮影にて心機能解析か ら冠動脈描出までone-stop shopとして可能であるた め，今後大いに普及する非侵襲的検査法であると考え る，今後の展開としては，MSCTの16列，さらには 256列への多チャンネル化，被曝量低減，時間分解能 のさらなる改善などが期待される．64列MSCTでは， $\beta$ 遮断薬やカルシウム拮抗薬による心拍数調整が不要 となり，撮影時間の短縮により心拍変動の影響を受け にくくなることが期待される．現在のシステムでは約 $100 \mathrm{ml}$ の造影剂を使用しているため，腎機能低下や心 不全患者においては使いにくい。また，検出器の多列 化に伴い被曝量が増加する。臨床的には診断結果が出 るまでに数時間を要する。このため緊急検査には対応 しづらく，即治療が必要となることが予想される場合 には心臟カテーテル検査となることが多い。カテーテ 儿操作が困難な解離性大動脈瘤や動脈瘤の患者, 安静
の保てない患者, 負荷心電図にて陽性の患者, 冠動脈 危険因子を持つ患者などを対象に検査を行っていく必 要がある。

\section{2. 結 語}

MSCTによって，臨床医はまず，冠動脈疾患におい て重要な冠動脈の情報(狭窄度, プラーク,リモデリ ング）を非侵襲的に知ることができる。そして，付録 として心機能の評価 (収縮能, 拡張能)や心筋性状評価 が可能となる. しかも，この心機能の情報は臨床的に 有用である. 冠動脈疾患で閉塞を起こしている人は, 水山の一角に過ざない，冠動脈危険因子を複数持つ人 のなかに閉塞をきたさない動脈壁の異常のみが存在す る病態がある。将来的にMSCTによる動脈壁の性状評 価が，最も重要であると考える．しかし，放射線被曝 と造影剤の使用の問題などは残されている。こういっ た欠点を克服する余地はあるものの, MSCTは循環器 画像診断のモダリティとして十分な価値を有すると考 える。また，臨床においてMSCTは非侵襲的に検査で きることで, 入院日数の減少, 撮影患者数の増加, 使 用造影剤の減少, 他の検査の減少などが見込まれ, 医 療経済的にも有用性を期待することができる．医療費 の個人負担が増加するなかで, MSCTで得られる情報 を有効に利用することで，患者の満足度を向上するう えでも意義があると考える，ただし，解析や画像の再 構成には放射線技師の大变な労力が必要であり, 今後 は解析の自動化などの発展が必要である.

\section{謝 辞}

滋賀医科大学附属病院放射線技師および放射線科医 師のMSCT検査の技術的な貢献に感謝する。 
参考文献

1) Nishizaki K, Yamazaki T, Fujiwara H, Japanese Coronary Intervention Study (JCIS) Group: Assessment of coronary intervention in Japan from the Japanese Coronary Intervention Study (JCIS) Group-Comparison between 1997 and 2000. Circ J, 68 (3), 181-185,(2004).

2）安野泰史：心臟CTの基本的撮影法. 画像診断，21(12), 1290-1296, (2001).

3) Matsuo S, Nakamura $Y$, Matsumoto $T$, et al.: Noninvasive evaluation of coronary artery plaque with ECG-gated multislice computed tomography. J Am Coll Cardiol, 43 (5), 363-364, (2004).

4) Matsuo S, Nakae I, Matsumoto T, et al.: Noninvasive evaluation of coronary artery plaque with electrocardiographicallygated multislice computed tomography. Computerized Medical Imaging and Graphics 2005 (in press).

5) Matsuo $S$, Nakamura $Y$, Matsumoto T, et al.: Visual assessment of coronary artery stenosis with electrocardiographicallygated multislice computed tomography. Int $\mathbf{J}$ Cardiovasc Imaging, 20(1), 61-66,(2004).

6) 松尾信郎，中村保幸，松本鉄也，他：マルチスライスCTに よる冠動脈病变評価に扔ける有用性の検討. 循環器科, 54 (5), 428-432, (2003).

7) Matsuo S, Matsumoto T, Nakae I, et al.: Evaluation of cardiac resynchronization therapy in drug-resistant idiopathic dilated cardiomyopathy by means of Tc-99m tetrofosmin electrocardiography-gated single-photon emission computed tomography. Exp Clin Cardiol, 9 (4), 248-250, (2004).

8) Matsuo S, Nakamura Y, and Kinoshita M: Poststress left ventricular function in patients with coronary artery disease using measured by Tl-201 ECG-gated SPECT. Exp Clin Cardiol, 7 (1), 30-34, (2002).

9) Matsuo S, Takahashi M, Nakamura Y, et al.: Evaluation of cardiac sympathetic innervation with iodine-123metaiodobenzylguanidine imaging in silent myocardial ischemia. J Nucl Med, 37(5), 712-717, (1996).

10) Matsuo S, Nakamura $Y$, Takahashi $M$, et al.: Myocardial metabolic abnormalities in hypertrophic cardiomyopathy assessed by iodine-123-labeled beta-methyl-branched fatty acid myocardial scintigraphy and its relation to exercise-induced ischemia. Jpn Circ J, 62 (3), 167-172, (1998).

11) Matsuo $S$, Nakamura $Y$, Tsutamoto $T$, et al.: Impairments of myocardial sympathetic activity may reflect the progression of myocardial damage or dysfunction in hypertrophic cardiomyopathy. J Nucl Cardiol, 9(4), 407-412,(2002).

12) Matsuo S, Matsumoto $T$, Nakae I, et al.: Impaired sympathetic nerve function may play an important role in enhancing coronary vasoconstriction in patients with hypertrophic cardiomyopathy. Circulation, 110(17), III-602 (Suppl.), (2004).

13) Matsuo S, Nakamura $Y$, and Kinoshita M: Warfarin reduces silent cerebral infarction in elderly patients with atrial fibrillation. Coronary Artery Dis, 9(4), 223-226, (1998).

14) Matsuo S, Matsumoto T, Nakae I, et al.: Anomaly of the left atrium in patients with atrial fibrillation detected by ECGgated multi-slice computed tomography. Int J Cardiovasc Imaging, 21 (4), 455-458, (2005). 